\title{
Confirming persistence of gluten intolerance in children diagnosed as having coeliac disease in infancy
}

\author{
Usefulness of one-hour blood xylose test
}

\author{
C. J. ROLlES, CHARLOTTE M. ANDERSON, and A. S. McNEISH \\ From the Institute of Child Health, University of Birmingham
}

\begin{abstract}
Rolles, C. J., Anderson, C. M., and McNeish, A. S. (1975). Archives of Disease in Childhood, 50, 259. Confirming persistence of gluten intolerance in children diagnosed as having coeliac disease in infancy: usefulness of onehour blood xylose test. In young infants the clinical and investigative features of coeliac disease (CD) may be mimicked by other conditions such as cow's milk intolerance or secondary disaccharidase deficiency. It is therefore especially important to confirm a diagnosis of $\mathrm{CD}$ by later gluten challenge in such infants.

Sixteen children in whom the diagnosis of $\mathrm{CD}$ had been made before the age of 12 months had an oral gluten challenge, after being treated with a gluten-free diet for periods of one month to 5 years. In 15 we showed intestinal xylose malabsorption by the one-hour blood xylose level within 1-28 days of starting ingestion of gluten. One child, with a persistently normal one-hour blood xylose test after gluten challenge for 3 months, had normal absorption and normal jejunal histology after 18 months on a gluten-containing diet; she is considered not to have CD.

The one-hour blood xylose test before and after gluten challenge can help to confirm the diagnosis in coeliac patients diagnosed in infancy.
\end{abstract}

In our recent experience most children with coeliac disease (CD) now present and are diagnosed before the age of one year (McNeish and Anderson, 1974) (Fig. 1). At this age the clinical and labora-

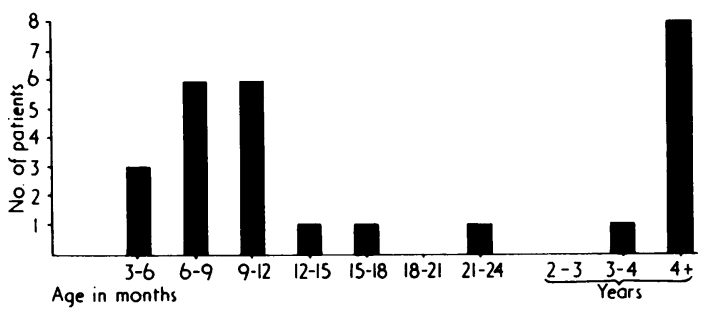

FIG. 1.-Age at diagnosis of the 27 new coeliac children presenting at Birmingham Children's Hospital in 1973.

tory findings of $\mathrm{CD}$, including jejunal histology, may be mimicked by secondary disaccharidase deficiency following gastroenteritis (Burke, Kerry,

Received 20 September 1974. and Anderson, 1965), or cow's milk protein intolerance (Visakorpi, Immonen, and Kuitunen, 1967). The apparent improvement of a 'coeliac' infant on a gluten-free diet may represent fortuitous recovery from one of these temporary conditions. It is therefore desirable to confirm the persistence of true gluten intolerance in these 'coeliac' infants before recommending a life-long gluten-free diet. We have found the one-hour blood xylose test (Rolles et al., 1973) to be a reliable index of malabsorption in childhood $\mathrm{CD}$. We have now assessed the usefulness of this test, before and after gluten challenge, as an indicator of continuing gluten sensitivity.

\section{Patients and methods}

Patients. We studied 16 children who were diagnosed as having CD when aged 3-11 months, and who were 6-68 months old at the time of the present investigation. Initially each had steatorrhoea, failure to thrive, and flat jejunal mucosa. All 14 children who had a one-hour blood xylose test had an abnormal result of $<20 \mathrm{mg} / 100 \mathrm{ml}$. All 16 children apparently responded 
symptomatically to a gluten-free diet. In 5 children clinical improvement was not obvious until after 7-10 days; 4 of these were severely ill, and the clinical and biochemical features were those of coeliac crisis, so that each infant was given a course of steriods.

The children remained on a gluten-free diet until they were readmitted to hospital for further investigation. The duration of gluten withdrawal ranged from one month to 5 years.

'Prechallenge' investigations. All 16 children had blood xylose tests on 2 consecutive days. The methods have been described previously; a normal value is more than $20 \mathrm{mg}$ xylose $/ 100 \mathrm{ml}$ blood one hour after $5 \mathrm{~g}$ oral D-xylose (Rolles et al., 1973). 10 children had a prechallenge jejunal biopsy to assess the degree of mucosal recovery.

Gluten challenge. Each child was given $10 \mathrm{~g}$ commercial gluten (Energen Foods Ltd.) in the morning and evening and the blood xylose test was repeated the next day. Gluten was then continued at the same dose until either xylose absorption fell or there were adverse clinical symptoms or signs. If no effects were noted after 7 days, the child was sent home on gluten $10 \mathrm{~g}$ twice daily, and a xylose test was perfomed in the outpatient department one week later. Thereafter, if no changes were observed, gluten was continued and a one-hour blood xylose test was repeated every 2 weeks.

When a low blood xylose result was found the test was repeated either the next day or within a few days, if the child was an outpatient. When there was a delay before repeating the test, gluten was continued. A challenge was only performed if the two base-line xylose results were within the normal range and were consistent with each other. A challenge was only considered to show a positive response if two results after gluten challenge were in the abnormal range $(<20 \mathrm{mg} / 100 \mathrm{ml})$.

\section{Results (Fig. 2 and Table)}

Xylose absorption. Of the 15 children who had a positive response to gluten challenge, 6 showed a fall in the one-hour blood xylose level the day after gluten was started, 4 showed a fall between 2 and 7 days, and 5 had the first evidence of xylose malabsorption between 14 and 28 days. Those who responded within a day had been on a glutenfree diet for 1-9 months (mean $4.6 \mathrm{~m}$ ), those who

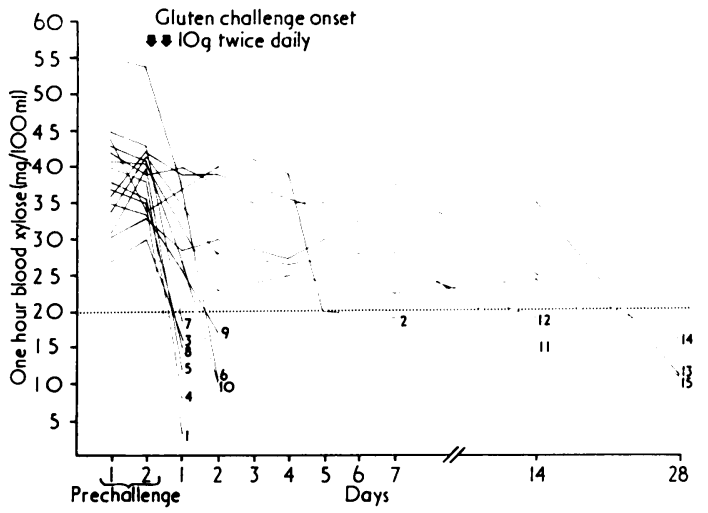

FIG. 2.-Serial one-hour blood xylose results after gluten challenge in Cases 1-15 (see text).

TABLE

Details of patients and investigations

\begin{tabular}{|c|c|c|c|c|c|c|c|c|c|}
\hline \multirow{2}{*}{$\begin{array}{c}\text { Case } \\
\text { no. }\end{array}$} & \multirow{2}{*}{ Sex } & \multirow{2}{*}{$\begin{array}{l}\text { Age } \\
(\mathrm{m}) \\
\text { at diagnosis } \\
\text { of } \mathrm{CD}\end{array}$} & \multirow{2}{*}{$\begin{array}{l}\text { Duration } \\
(\mathrm{m}) \\
\text { of gluten- } \\
\text { free diet }\end{array}$} & \multirow{2}{*}{$\begin{array}{c}\text { Duration } \\
\text { (d) } \\
\text { of gluten } \\
\text { challenge }\end{array}$} & \multicolumn{2}{|c|}{$\begin{array}{l}\text { Histological grade } \\
\text { of jejunal mucosa }\end{array}$} & \multirow{2}{*}{$\begin{array}{c}\text { Symptoms } \\
\text { after } \\
\text { challenge } \\
\text { (see text) }\end{array}$} & \multicolumn{2}{|c|}{$\begin{array}{l}\text { One-hour blood } \\
\text { xylose }(\mathrm{mg} / 100 \mathrm{ml})\end{array}$} \\
\hline & & & & & $\begin{array}{c}\text { Before } \\
\text { challenge }\end{array}$ & $\begin{array}{c}\text { After } \\
\text { challenge }\end{array}$ & & $\begin{array}{c}\text { Before } \\
\text { challenge }\end{array}$ & $\begin{array}{c}\text { After } \\
\text { challenge }\end{array}$ \\
\hline $\begin{array}{r}1 \\
2 \\
3 \\
4 \\
5 \\
6 \\
7 \\
8 \\
9 \\
10 \\
11 \\
12 \\
13 \\
14 \\
15 \\
16\end{array}$ & $\begin{array}{l}M \\
F \\
M \\
M \\
F \\
M \\
M \\
M \\
F \\
F \\
F \\
M \\
F \\
F \\
F \\
F\end{array}$ & $\begin{array}{r}10 \\
5 \\
5 \\
3 \\
11 \\
7 \\
10 \\
9 \\
3 \\
8 \\
9 \\
10 \\
5 \\
8 \\
8 \\
4\end{array}$ & $\begin{array}{r}1 \\
2 \\
2 \\
3 \\
4 \\
5 \\
7 \\
9 \\
10 \\
10 \\
12 \\
12 \\
24 \\
48 \\
60 \\
12\end{array}$ & $\begin{array}{l}1 \\
7 \\
1 \\
1 \\
1 \\
2 \\
1 \\
1 \\
2 \\
4 \\
14 \\
14 \\
28 \\
28 \\
28 \\
18 \mathrm{~m}\end{array}$ & $\begin{array}{c}-2 \\
- \\
3 \\
1 \\
1 \\
1 \\
- \\
- \\
1 \\
1 \\
1 \\
1 \\
1\end{array}$ & $\begin{array}{l}- \\
- \\
\bar{Z} \\
- \\
- \\
- \\
- \\
- \\
3 \\
4 \\
4 \\
4 \\
1\end{array}$ & $\begin{array}{l}0 \\
\pm \\
0 \\
++ \\
+ \\
\pm \\
0 \\
0 \\
0 \\
0 \\
+ \\
0 \\
0 \\
0 \\
0 \\
0\end{array}$ & $\begin{array}{l}35 \\
40 \\
30 \\
38 \\
40 \\
41 \\
43 \\
35 \\
34 \\
47 \\
34 \\
41 \\
40 \\
42 \\
40 \\
37\end{array}$ & $\begin{array}{r}14 \\
19 \\
16 \\
3 \\
12 \\
10 \\
19 \\
15 \\
16 \\
10 \\
15 \\
18 \\
16 \\
11 \\
16 \\
44\end{array}$ \\
\hline
\end{tabular}

*Grade 1, normal: finger or leaf villi, epithelium normal; 2 , villi broadened: irregularity of epithelial cell heights; increase of cells in lamina propria; 3, fused, stunted villi: moderate infiltrate in lamina propria; 4, absence of villi: crypt hyperplasia. 
responded at 2-7 days had been on a gluten-free diet for 2-10 months (mean $6 \cdot 7 \mathrm{~m}$ ), while those who responded at 14-28 days had a gluten-free diet for 12-60 months (mean $30 \mathrm{~m}$ ).

Jejunal histology. 10 children had a jejunal biopsy before the gluten challenge. In 7 the histology was normal; in 2 there was partial but incomplete mucosal regeneration; in 1 biopsy (Case 5) there were fused, stunted villi, only slightly improved when compared to the patient's original untreated biopsy.

The 5 children who were challenged with gluten for 14 days or longer had a biopsy at the end of the challenge. In 4 (Cases 12-15) the mucosa had reverted to the classic flat picture seen in untreated CD. In Case 16 the mucosa remained normal; this child is discussed below.

Clinical effects of challenge. 11 children were asymptomatic throughout the investigation. Case 4 developed moderately severe diarrhoea and vomiting within 4 hours of the first dose of $10 \mathrm{~g}$ gluten. No further gluten was given, and the child was clinically normal the next day, though xylose absorption remained low for a further 2 days. This child was one of the youngest to be challenged (aged 6 months). Case 5 had two bulky motions after the first two doses of gluten, Cases 2 and 6 had mild diarrhoea, and Case 11 developed anorexia on day 10.

Case 16. This girl was diagnosed as having coeliac disease at the age of 4 months. She had steatorrhoea, xylose malabsorption, and severe enteropathy (Fig. 3). No pathogens were isolated from her stools. At the time of diagnosis she was severely ill and had intravenous fluids and steroids for a few days. She progressed slowly for the next 10 days, when Esch. coli $\mathrm{O} 114$ was isolated from her stools. Gentamicin was given orally and parenterally and she made a steady and sustained recovery. After one year on a gluten-free diet she had a gluten challenge lasting 3 months without ill effects. She returned to a normal diet and has thrived since. Intestinal biopsies obtained 3, 6, and 18 months after gluten reintroduction were all normal.

\section{Discussion}

In the past few years infants with $C D$ have presented at a progressively earlier age, so that the majority are under 1 year at diagnosis, and 10-15\% are less than 6 months old (McNeish and Anderson, 1974) (Fig. 1). This trend probably results from the current practice in the U.K. of very early introduction of cereals into the diet. Such young infants often have a history of vomiting, diarrhoea,

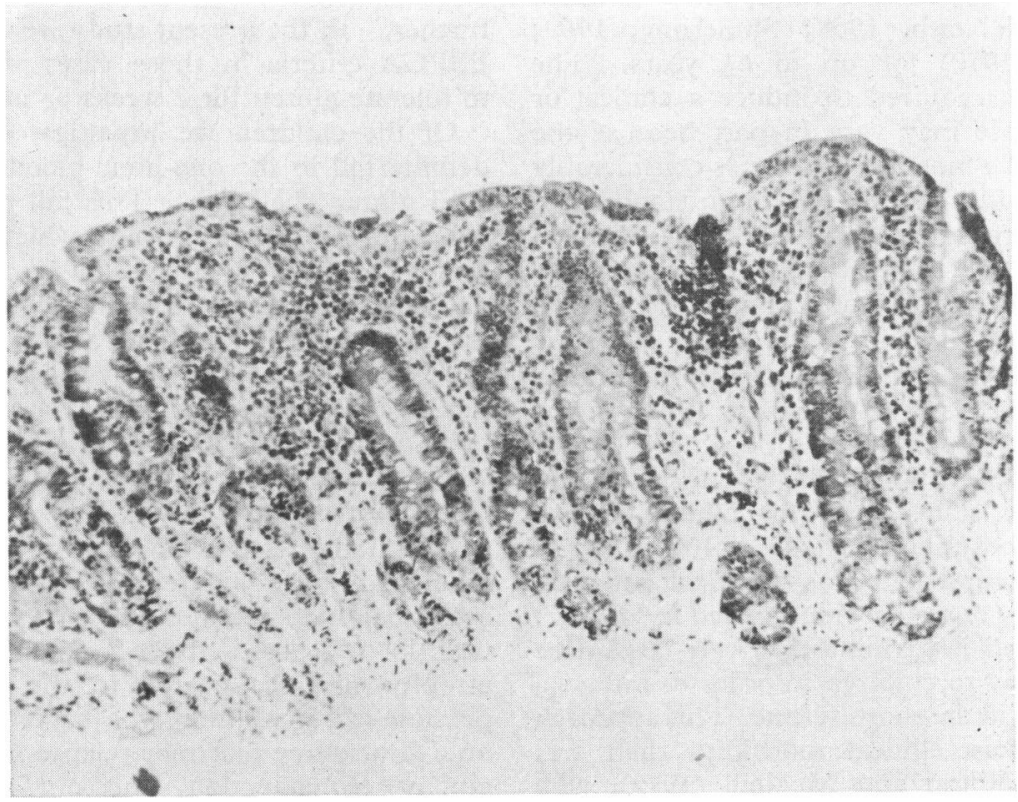

Fig. 3.-Case 16. Photomicrograph of jejunal bropsy at original diagnusts at age 4 months. $(\times 150$. 
and failure to thrive for a few weeks only. The differential diagnosis includes cow's milk protein intolerance (Visakorpi et al., 1967) and secondary disaccharidase deficiency (Burke et al., 1965), as well as coeliac disease. In all three conditions there may be steatorrhoea, reducing substances in the stools, low levels of serum iron and folate, and severe mucosal changes in the jejunum (Anderson, 1966; Visakorpi et al., 1967; Liu et al., 1968). Furthermore, the conditions may overlap or coexist, since cow's milk protein intolerance has been found in children later shown to have $C D$ (Visakorpi and Immonen, 1967) and lactose intolerance is a known complication of CD (Arthur et al., 1966; McNeish and Sweet, 1968). Lastly, a condition of temporary gluter intolerance probably exists (Walker-Smith, 1970), though few convincing cases have been described.

A satisfactory clinical, biochemical, and histological response to a gluten-free diet is now part of the widely accepted definition of childhood CD (Meeuwisse, 1970). Spontaneous recovery of all these parameters may also occur in the temporary states of cow's milk protein intolerance or secondary disaccharidase deficiency. If infants with these conditions are erroneously thought to have $C D$, a gluten-free diet may be needlessly continued indefinitely. Gluten challenge in such children seems justifiable and even desirable.

The regimen of gluten reintroduction has varied widely. Some workers have simply reintroduced a normal diet (McNeish, 1968; Shmerling, 1969; Walker-Smith, 1970) for up to $6 \frac{1}{2}$ years. The variation in time required to induce a clinical or histological relapse may vary in part because the gluten content of a 'normal' diet varies considerably among individuals. In an attempt to standardize the challenge procedure, Hamilton and McNeill (1972) used one slice of bread a day (approximately $2 \cdot 25 \mathrm{~g}$ gluten) as a 'small uniform dose' for periods of up to 15 months.

In adults the dosage of gluten also varies widely, from 20-30 g (Bayless and Swanson, 1964; Weinstein, 1974) to as much as $100-150 \mathrm{~g} /$ day (Levine et al., 1966) used for up to 8 weeks to assess gluten toxicity. Levine states that (for adults), 'As a screening test for gluten toxicity a $100 \mathrm{~g}$ gluten "cocktail" was found to be as practical and well tolerated as lower doses previously used by others'.

We felt justified in giving a relatively large dose of $20 \mathrm{~g}$ gluten/day to children in order to induce a definitive change in the shortest time. This approach produced no more clinical morbidity than was reported by Hamilton and McNeill (1972), who gave only $2 \cdot 25$ g gluten daily. By adding a known amount of powdered gluten to an otherwise glutenfree diet we have also avoided accustoming our patients to the taste of ordinary gluten-containing foods which might be subsequently forbidden again.

There has been no uniformity among authors in selecting criteria for a relapse of $\mathrm{CD}$ after gluten reintroduction. A positive response has been defined as the appearance of clinical symptoms (Sheldon, 1959; Visakorpi and Immonen, 1967); the appearance of antibodies to gluten in the serum (Pelkonen and Visakorpi, 1970); the appearance of circulating immune complexes in the serum (Doe, Booth, and Brown, 1973); IgA deposition in the basement membrane of the jejunal epithelium (Shiner and Ballard, 1972); and the reappearance of villous atrophy in the small intestine (McNeish, 1968; Shmerling, 1969; Hamilton and McNeill, 1972). The full diagnostic criteria suggested by the European Society of Paediatric Gastroenterology (Meeuwisse, 1970) require a minimum of 3 intestinal biopsies, though in fact these criteria are often not fulfilled in published descriptions of coeliac disease by reputable workers.

A practical difficulty arises when trying to meet these diagnostic requirements in young infants because their symptomatic response to gluten reintroduction may be very rapid. The histological changes in the jejunal mucosa at this time may be mild, or difficult to interpret, in the current state of knowledge. This aspect is being investigated further. In the present study we have fulfilled the ESPGA criteria in those cases which were able to tolerate gluten for 2 weeks or more.

Of the children we investigated, 15 showed a definite fall in the one-hour blood level 1-28 days after gluten challenge. This fall tended to appear most quickly in those cases which had been on a gluten-free diet for less than 6 months, and who not surprisingly had residual histological abnormalities in the jejunum (Table). However, it is noteworthy that xylose malabsorption was rapidly produced in several children (Cases 7-10) who had been on a gluten-free diet for 7-10 months, even when the prechallenge jejunal histology was known to be normal (Cases 7 and 8).

Functional relapse took longest in the 3 children who had been treated for several years. An abnormal blood xylose test was found within 28 days in these cases, by which time severe villous atrophy had reappeared in the jejunum. It is possible that children who have been even longer on a gluten-free diet may relapse more slowly after gluten reintroduction, and our preliminary observations have tended to confirm this. 
The clinical effects of gluten challenge were generally mild or absent. The only infant who had moderate symptoms was the youngest to have a gluten challenge. In retrospect, it would have been wiser to delay his challenge until he had been on a gluten-free diet for a longer period. Case 1 had been on a gluten-free diet for only 1 month when challenged. This was probably too brief a period to exclude the possibility of a temporary gluten intolerance. Case 16 showed no abnormality of xylose absorption after prolonged gluten challenge, and subsequent follow-up suggests that she does not have CD. It can be argued that her jejunal mucosa may yet relapse morphologically after more than 18 months of ingesting gluten (Shmerling, 1969). A more likely explanation is that she had an enteropathy associated with infection, with or without temporary gluten intolerance.

From our data, we suggest that gluten challenge of 'coeliac' infants should be performed 6-12 months after the onset of treatment, when they are clinically well, but not before the age of one year.

The basic defect in CD is still unknown. Until it is discovered, the diagnosis of $\mathrm{CD}$ will continue to be based on the clinical, biochemical, and histological consequence of gluten withdrawal and reintroduction. We suggest that the procedure described in this paper may help to increase the accuracy of diagnosis in young infants.

We are grateful to our consultant colleagues for referring some of the patients; to Dr. A. H. Cameron for histological reporting; and to Energen Foods Ltd. for supplying samples of gluten. C.J.R. was supported by the Children's Research Fund.

\section{REFBRENCES}

Anderson, C. M. (1966). Intestinal malabsorption in childhood. Archives of Disease in Childhood, 41, 571 .

Arthur, A. B., Clayton, B. E., Cottom, D. G., Seakins, J. W. T., and Platt, J. W. (1966). Importance of disaccharide intolerance in the treatment of coeliac disease. Lancet, 1, 172.

Bayless, T. M., and Swanson, V. L. (1964). Comparison of tropical sprue and adult celiac disease. (Abst.) Gastroenterology, 46, 731 .
Burke, V., Kerry, K. R., and Anderson, C. M. (1965). The relationship of dietary lactose to refractory diarrhoea in infancy. Australian Paediatric fournal, $1,147$.

Doe, W. F., Booth, C. C., and Brown, D. L. (1973). Evidence for complement-binding immune complexes in adult coeliac disease, Crohn's disease, and ulcerative colitis. Lancet, 1, 402.

Hamilton, J. R., and McNeill, L. K. (1972). Childhood celiac disease: response of treated patients to a small uniform daily dose of wheat gluten. Fournal of Pediatrics, 81, 885.

Levine, R. A., Briggs, G. W., Harding, R. S., and Nolte, L. B. (1966). Prolonged gluten administration in normal subjects. New England fournal of Medicine, 274, 1109.

Liu, H. Y., Tsao, M. U., Moore, B., and Giday, Z. (1968). Bovine milk protein-induced intestinal malabsorption of lactose and fat in infants. Gastroenterology, 54, 27.

McNeish, A. S. (1968). The diagnosis of coeliac disease in retrospect. Archives of Disease in Childhood, 43, 362.

McNeish, A. S., and Anderson, C. M. (1974). Celiac disease: the disorder in childhood. Clinics in Gastroenterology, 3, 127.

McNeish, A. S., and Sweet, E. M. (1968). Lactose intolerance in childhood coeliac disease: assessment of its incidence and importance. Archives of Disease in Childhood, 43, 433.

Meeuwisse, G. W. (1970). Diagnostic criteria in coeliac disease. Round Table Discussion, European Society of Paediatric Gastroenterology. Acta Paediatrica Scandinavica, 59, 461.

Pelkonen, P., and Visakorpi, J. K. (1970). Precipitins to cow's milk and gluten, and the serum level of $\mathrm{IgA}$ in the follow-up of coeliac patients. Acta Paediatrica Scandinavica, 59, 453.

Rolles, C. J., Kendall, M. J., Nutter, S., and Anderson, C. M. (1973). One-hour blood-xylose screening-test for coeliac disease in infants and young children. Lancet, 2, 1043.

Sheldon, W. (1959). Celiac disease. Pediatrics, 23, 132.

Shiner, M., and Ballard, J. (1972). Antigen-antibody reactions in jejunal mucosa in childhood coeliac disease after gluten challenge Lancet, 1, 1202.

Shmerling, D. H. (1969). An analysis of controlled relapses in gluten-induced coeliac disease. Acta Paediatrica Scandinavica 58, 311.

Visakorpi, J. K., and Immonen, P. (1967). Intolerance to cow's milk and wheat gluten in the primary malabsorption syndrome in infancy. Acta Paediactrica Scandinavica, 56, 49.

Visakorpi, J. K., Immonen, P., and Kuitunen, P. (1967). Malabsorption syndrome in childhood: the occurrence of absorption defects and their clinical significance. Acta Paediatrica Scandinavica, 56, 1.

Walker-Smith, J. (1970). Transient gluten intolerance. Archives of Disease in Childhood, 45, 523.

Weinstein, W. M. (1974). Coeliac Disease. Ed. by W. Th. J. M. Hekkens and A. S. Peña. 2nd International Coeliac Symposium, Leiden, 1974 . Stenfert Kroese, Leiden.

Correspondence to Dr. C. J. Rolles, Institute of Child Health, University of Birmingham, Birmingham B16 8ET. 